\title{
An Evaluation of the Effect of the Biological Dose of Fluoroscopic Radiation Exposure in the Operating Room
}

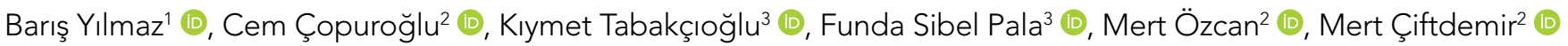 \\ ${ }^{1}$ Clinic of Orthopedics and Traumatology, Fatih Sultan Mehmet Traning and Research Hospital, i̇stanbul,Turkey \\ ${ }^{2}$ Department of Orthopedics and Traumatology, Trakya University School of Medicine, Edirne, Turkey \\ ${ }^{3}$ Department of Medical Biology, Trakya University School of Medicine, Edirne, Turkey \\ Cite this article as: Yılmaz B, Çopuroğlu C, Tabakçıoğlu K, Pala FS, Özcan M, Çiftdemir M. An Evaluation of the Effect of the Biological Dose \\ of Fluoroscopic Radiation Exposure in the Operating Room. JAREM 2018; 8: 19-24.
}

\begin{abstract}
Objective: Through an evaluation of the biological dose, we aimed to evaluate the risks of ionizing radiation to which physicians and auxiliary healthcare personnel working in orthopedic operating rooms are exposed to via diagnostic use of fluoroscopy.

Methods: Blood samples were collected from physicians and auxiliary healthcare personnel working in the orthopedic operating room. The biological dose was evaluated using micronucleus and dicentric analysis. To assess the effects of physical and chemical agents together, a total of 31,000 binucleate cells were evaluated using the micronucleus method and 16,500 metaphase plaques were evaluated using dicentric analysis, which is accepted as the most important indicator in determining the effects of radiation.

Results: The study participants comprised 18 males and 5 females ( 16 physicians, 4 nurses, and 3 patient carers) with a mean age of 34.1 years (range, 22-58 years) who were thought to have been exposed to ionizing radiation in the working environment. The mean duration of working under ionizing radiation was 73.6 months (range, 1.5-420 months). In the blood samples, the total micronucleus frequency was determined as $8.8 \pm 1.4$. In the evaluation of the 16,500 metaphysis plaques, radiation-specific dicentric was observed in 5 subjects (normal frequency: $5 / 10,000$ ). As a result of the analysis made use both methods, the dose was determined to be slightly above background level, and below risk level in 6 subjects. The dose was related with medical applications in 4 of these subjects.

Conclusion: Fluoroscopy should be attempted in the operating room within a restricted time as far as possible and at measurements of high $\mathrm{kV}$ and low $\mathrm{mA}$. $\mathrm{kV}$-mA values are of utmost importance for providing the best results according to the nature of the operation; the tube outlet is predefined away from the patient's skin.
\end{abstract}

Keywords: Fluoroscopy, micronucleus, dicentric analysis

ORCID IDs of the authors: B.Y. 0000-0003-2023-267X; C.Ç. 0000-0002-3884-3711; K.T. 0000-0002-7345-0825; F.S.P. 0000-0002-5523-5160; M.Ö. 0000-00022009-1881; M.Ç. 0000-0002-9677-2819

\section{INTRODUCTION}

Fluoroscopy is a method of imaging frequently used in the operating room environment that allows the operations to be completed quickly and safely. $\mathrm{X}$ rays used in fluoroscopy contain ionizing radiation, and this ionizing radiation is of great health importance since it can damage biological systems, especially in cells when it, directly or indirectly, damages DNA, in which all vital and hereditary information is contained. In direct effect, the radiation energy directly breaks the chemical bonds of DNA molecules, thus disrupting their structure. Indirectly, however, it causes the formation of free radicals by performing radiolysis on water molecules around the radiation molecule (1-4).

lonizing radiation causes ionization of liquid and gaseous substances, while interaction of solid materials causes secondary radiation to be emitted from these substances. Therefore, the body parts of the patients irradiated with ionizing radiation and the secondary radiation emitted from other solid substances exposed to radiation will always be present in the environment. Secondary radiation is a longwave radiation that can propagate in all directions. Therefore, occupational radiation is the secondary radiation, and individuals working with medical radiation are consistently exposed to it. Since the secondary radiation's capability to penetrate is weak, it cannot penetrate the body and becomes absorbed by the body. This radiation that is taken into the body is a kind of energy in the physical sense. As a result, this intake of such low-energy radiation into the body for years can result in harmful effects on cells, tissues, organs, and body systems. The symptoms of these harmful effects are becoming more evident from the first decade, and the damage increases over time $(5,6)$. 
To prevent health care staff risk their own health while trying to improve the health of others, it is very important to identify the risks and take precautions among the health care staff who use radiation and radioactivity for diagnostic and therapeutic purposes. In this study, we aimed to evaluate the biological dose on physicians and assistant health care personnel working in orthopedic operation rooms to measure the effect of ionizing radiation caused by fluoroscopy used for diagnostic purposes in the operating rooms.

\section{METHODS}

We requested the physicians, nurses, and caregivers working in the Clinic of Orthopedics and Traumatology participate in our study on a volunteer basis. Their verbal consents were obtained, and our study was prepared in accordance with the Declaration of Helsinki. First of all, participants in the study were given a survey that included demographic information. The first part of the questionnaire consisted of general information. Participants were asked questions about their smoking, alcohol, and caffeinated beverage habits; drug use; metabolic diseases; and radiological practices that they had been exposed to for diagnostic or therapeutic purposes. The second part of the questionnaire contained information on their working environment: the duration and conditions of working with the scoping device, the precautions taken to protect from the radiation, and the ones who were thought to be exposed to physical and/or chemical agents in the working environment were analyzed in detail. Considering the answers given in the questionnaire, individuals who exceeded the effective dose limit for a consecutive 5-year average or any year, those who were on regular medication and with harmful habits that could disrupt the blood values, and those with a metabolic disease were not included in our study. People working in an environment with a scoping device or those who declared that they did not wear protective gowns were evaluated under the category "Exposed to Radiation".

Of the 23 participants in our study, 18 (78.2\%) were male and 5 (21.8\%) were female, and the average age was 34.1 (22-58). Of our participants, $16(69.5 \%)$ were physicians, $4(17.4 \%)$ were nurses, and $3(13.1 \%)$ were caregivers.

Blood samples of the participants were taken into dysenteric analysis for 48 hours and the micronucleus (MN) analysis for 68 hours. In the culture analysis, the RPMI1640 cell culture medium, $10 \%$ fetal bovine serum, and $1 \%$ penicillin-streptomycin were used. Cells were induced with phytohemagglutinin. The slides dyed with the Giemsa stain method were evaluated under a light microscope (Olympus America Inc., Model No: B51, Center Valley, PA, USA).

Finally, biological dosing was performed using the $\mathrm{MN}$ and dysenteric analysis methods from the blood samples taken from the participants. The increase in the number of micronuclei was regarded as an indirect indicator of the numerical and structural chromosomal irregularities produced by the various agents in the cells. A total of 31,000 binucleate cells and 16,500 metaphase plaques for the analysis of the dysenterics were evaluated for this method, which allowed evaluating the effects of physical or chemical agents.

\section{RESULTS}

The average time during which the subject personnel were exposed to ionizing radiation in the working environment was 73.6 (1.5-420) months.

According to the results of a $\mathrm{MN}$ analysis, the total MN frequency of the study group was determined as $8.8 \pm 1.4$. Five individuals had the MN frequency above the background level.

A metaphase analysis was performed on 16,500 metaphase plaques (Table 1) (Figures 1-3). In the obtained data, 6 persons were observed to be radiation-specific dysenteric (natural frequency 5/10000). Of these, the biological doses of 4 were identified with medical applications. It was concluded that only 2 physicians (9 and 10) were exposed to low-dose radiation (Table 2).

As a result of the analysis that used both methods, 6 (26.1\%) subjects were determined to have slightly above-the-background level and below-the-risk-level dose.

\section{DISCUSSION}

A total of $88 \%$ of the ambient radiation we are exposed to in our daily lives is natural radiation emitted by the sun rays, cosmic rays, and radioactive substances, whereas $12 \%$ is the artificial radiation generated by medical radiation, waste, consumer products, occupational exposure, and radioactive fallout. A significant portion of this artificial radiation is includes medical radiation, at $96.6 \%(1)$.

Apart from patients, one of the most important groups affected by medical radiation is the health care personnel working with fluoroscopy in the operating room environment. Doctors, nurses, and assistant health care personnel in this group are exposed to radiation at different durations and doses. Although the use of personal protective equipment is compulsory, sometimes the doses received by persons can exceed the permitted limits due to the inadequate and insufficient use of the personal protective equipment and the necessities arising during the operation. In this case, it is more likely that people will be more affected by the damaging effects of radiation than they are supposed to be $(7,8)$. For this reason, various methods have been developed to determine the exposure level of radiation workers. First of all, radiation workers have to carry dosimetry regularly. By checking these dosimeters at regular intervals, the dose received by the individual is monitored. Another approach is to determine how people are affected by radiation biologically at the cellular level. The most commonly used methods are the MN method and the analysis of dysenteric chromosomes. The MN testing has become a widely used technique in the detection of cytogenetic damage, with the advantage that it can be more easily applied compared to chromosome analysis, that it has more cell counts, and more meaningful statistical results (9-18). 
Table 1. Detailed analysis of personnel thought to be exposed to physical and/or chemical agents in the working environment

\begin{tabular}{|c|c|c|c|c|c|c|c|c|c|}
\hline No & Age & $\mathbf{S}$ & Occupation & $\begin{array}{l}\text { Working } \\
\text { Period }\end{array}$ & $\begin{array}{l}\text { Physical } \\
\text { Agent }\end{array}$ & $\begin{array}{l}\text { Chemical } \\
\text { Agent }\end{array}$ & MN & Dysenteric & Comment \\
\hline 1 & 58 & M & Physician & 32 year & No & No & 9/1200 & $0 / 500$ & MN frequency is within natural limits \\
\hline 2 & 38 & $\mathrm{~F}$ & Nurse & 18 year & No & Yes & $10 / 1000$ & $0 / 500$ & MN frequency is within natural limits \\
\hline 3 & 42 & M & Physician & 15 year & Yes & Yes & $36 / 2500$ & $1 / 2000$ & $\begin{array}{l}04 \mathrm{MN} \text { (Scoping) } \\
0.008 \mathrm{Dic}\end{array}$ \\
\hline 4 & 36 & M & Physician & 10 year & Yes & Yes & $17 / 1000$ & $1 / 1000$ & $\begin{array}{l}\text { 0.04 Gy MN (scoping) } \\
0.012 \text { GyDic (X-Ray+scoping) }\end{array}$ \\
\hline 5 & 37 & M & Physician & 10 year & No & Yes & $8 / 1000$ & $1 / 2000$ & $\begin{array}{l}\text { MN frequency is within natural limits } \\
0.005 \text { GyDic ( } 3 \text { PA graphy) }\end{array}$ \\
\hline 6 & 39 & M & Physician & 5 year & Yes & Yes & $7 / 1000$ & $0 / 500$ & MN frequency is within natural limits \\
\hline 7 & 33 & M & Physician & 5 year & No & Yes & $7 / 1000$ & $0 / 500$ & $\begin{array}{l}\text { MN frequency is within natural limits. } \\
\text { Due to past exposure to radiation } \\
\text { applications, more than one } \mathrm{MN} \text { in one } \\
\text { cell and a high acentric ratio were } \\
\text { observed. }\end{array}$ \\
\hline 8 & 30 & M & Physician & 5 year & Yes & Yes & $14 / 1000$ & $0 / 500$ & 0.02 Gy MN (CT+PA X-Ray) \\
\hline 9 & 31 & M & Physician & 4,5 year & Yes & Yes & $48 / 3000$ & $1 / 1500$ & $\begin{array}{l}\text { 0.04 MN (scoping) } \\
\text { 0.005 Dic (scoping) }\end{array}$ \\
\hline 10 & 35 & M & Physician & 4 year & Yes & Yes & $10 / 1000$ & $2 / 2500$ & $\begin{array}{l}\text { MN frequency is within natural limits } \\
0.01 \mathrm{~Gy}(\mathrm{CT})\end{array}$ \\
\hline 11 & 26 & M & Physician & 3 year & Yes & Yes & $12 / 2500$ & $0 / 500$ & MN frequency is within natural limits \\
\hline 12 & 27 & M & Physician & 3 year & No & Yes & $10 / 1250$ & $0 / 500$ & MN frequency is within natural limits \\
\hline 13 & 28 & $\mathrm{~F}$ & Physician & 3 year & No & Yes & $7 / 1550$ & $0 / 500$ & MN frequency is within natural limits \\
\hline 14 & 32 & M & Physician & 3 year & Yes & Yes & $12 / 2500$ & $0 / 500$ & MN frequency is within natural limits \\
\hline 15 & 45 & M & Caregiver & 2 year & No & Yes & $10 / 1000$ & $0 / 500$ & MN frequency is within natural limits \\
\hline 16 & 39 & $\mathrm{~F}$ & Nurse & 2 year & No & No & $7 / 1000$ & $0 / 500$ & $\begin{array}{l}\text { MN frequency is within natural limits } \\
\text { (more acentric graphy) }\end{array}$ \\
\hline 17 & 43 & M & Caregiver & 18 months & No & No & $9 / 1000$ & $0 / 500$ & MN frequency is within natural limits \\
\hline 18 & 25 & M & Physician & 1 year & Yes & Yes & $12 / 1500$ & $0 / 500$ & MN frequency is within natural limits \\
\hline 19 & 30 & M & Physician & 1 year & No & Yes & $5 / 1000$ & $0 / 500$ & MN frequency is within natural limits \\
\hline 20 & 22 & $\mathrm{~F}$ & Nurse & 9 months & Yes & Yes & $5 / 1000$ & $0 / 500$ & $\begin{array}{l}\text { MN frequency is within natural limits } \\
\text { (more acentric graphy) }\end{array}$ \\
\hline 21 & 30 & M & Caregiver & 8 months & Yes & Yes & $6 / 1000$ & $0 / 500$ & MN frequency is within natural limits \\
\hline 22 & 25 & M & Physician & 4 months & Yes & Yes & $8 / 1000$ & $0 / 500$ & MN frequency is within natural limits \\
\hline 23 & 22 & $\mathrm{~F}$ & Nurse & 1.5 months & No & Yes & $7 / 1000$ & $0 / 500$ & MN frequency is within natural limits \\
\hline
\end{tabular}

Initially used to detect the effects of physical agents, the MN was used to determine the damage on genetic material caused by the radiological accident that took place in Goiânia (Brazil) on September 13, 1987. A very significant increase in the MN frequency due to the dose of ionizing radiation was observed, and it was suggested that the $\mathrm{MN}$ test be used as a biological dosimeter. In addition, the cytogenetic changes in people exposed to Goiânia accident were evaluated considering not only by ionizing radiation, but also the other factors such as age and lifestyle (alcohol consumption, smoking) (19).

In our study, apart from the MN method that allowed us to evaluate the effects of physical and chemical agents together, we also studied metaphase plaques for dysenteric analysis, which is considered to be the most important indicator in determining the effects of radiation. Although we found the average MN frequency for the control group to be similar to the mean values of total 

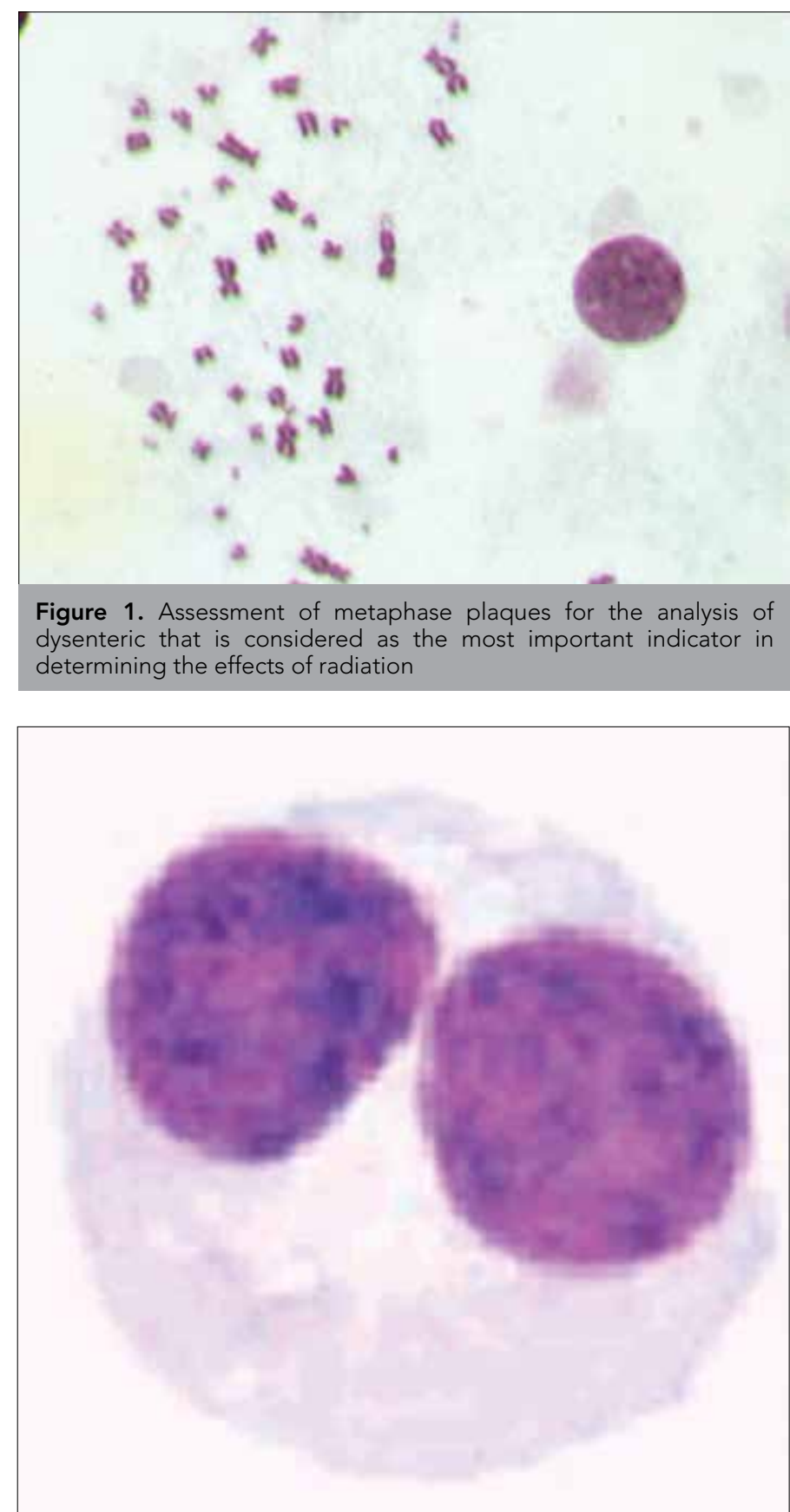

Figure 2. Microscopic view of a normal binucleate cell

MN frequencies in the blood of the participant's, it was extremely important that we observed the radiation specific dysenteric in 5 individuals, and the analysis of both methods showed that the radiation dose determined in $6(26.1 \%)$ participants was slightly above the background level and below the risk level. We associated $4(17.4 \%)$ of these participants with medical applications. The result we have achieved is that the exposure to ionizing radiation in the orthopedic operating room on a daily basis is at a level that needs serious attention. The limits of our study were that it was conducted with a limited number of orthopedic operating room personnel, and although we knew how long the participants had been working in the subject environment in

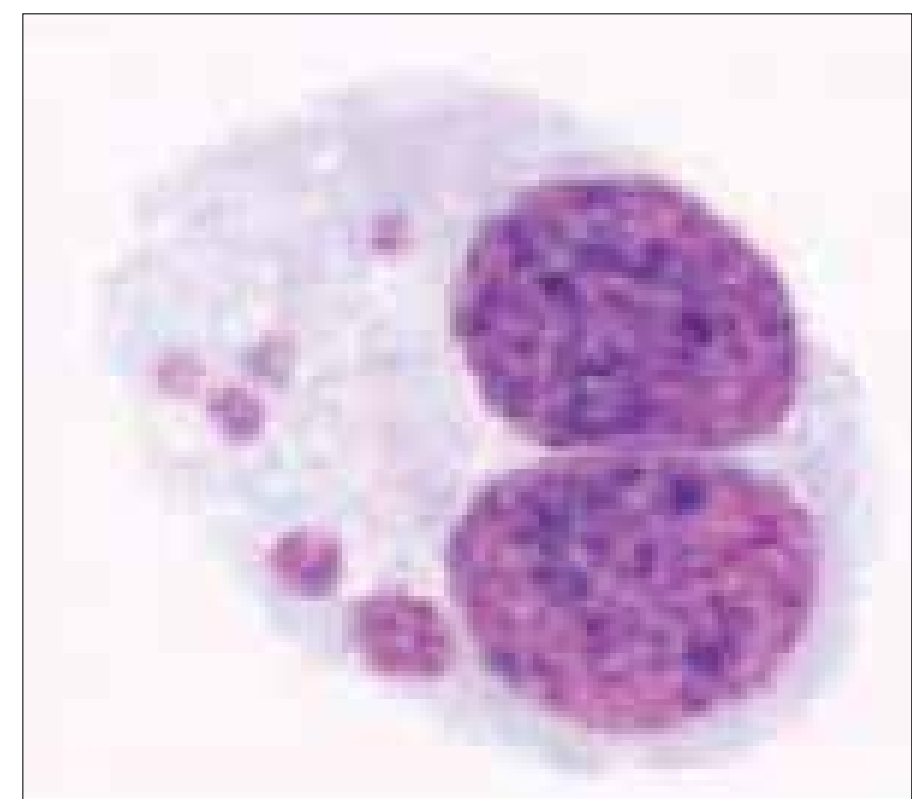

Figure 3. Microscopic view of a binucleate cell with micronucleus

terms of years, the exact amount of ionized radiation that they were exposed to during this period was not known in detail, and the participants' protection from radiation was not standardized. However, to the best of our knowledge, our study was the first to have been performed specifically on orthopedic operating room personnel, and their average working history being over 5 years have made our study valuable. At this point, it can easily be inferred that the staff working with fluoroscopy should be in the same category as radiology or radiation oncology personnel who are to carry a dosimeter, and their portable dosimetry is to be recorded.

The inclusion criteria were the following: working in the operating room environment; no smoking, alcohol, or caffeinated beverage habits; having no chronic drug use; having no metabolic diseases; and not being exposed to any radiological practices for diagnostic and/or therapeutic purposes. Those who exceeded the average effective radiation dose limit in a consecutive 5-year period or in any year, those who were on a regular medication and who had harmful habits that could disrupt their blood values, and those who had metabolic diseases were excluded from the study.

\section{CONCLUSION}

It is very important to make the necessary measurements and to use the radiation in a controlled manner to ensure the radiation safety of individuals who use ionizing radiation resources and who are exposed to it in an environment. The dose taken by the patient in a scoping examination ranges between 0.05 or $0.1 \mathrm{~Gy}$ per minute, and the total dose taken by those in the environment might be very large if the session gets longer than it should be $(20,21)$. For this reason, a time limit should always be used, and this limit must be observed. A high $\mathrm{kV}$ and low $\mathrm{mA}$ should be used under possible limits. The most effectual $\mathrm{kV} / \mathrm{mA}$ values for different patient thicknesses and tube output and patient skin 
Table 2. Cases with above average mononuclear cell incidence

\begin{tabular}{|l|c|c|c|c|c|c|c|l|l|}
\hline No & Age & S & Occupation & $\begin{array}{c}\text { Working } \\
\text { Period }\end{array}$ & $\begin{array}{c}\text { Physical } \\
\text { Agent }\end{array}$ & $\begin{array}{c}\text { Chemical } \\
\text { Agent }\end{array}$ & MN & Dysenteric & Comment \\
\hline 3 & 42 & M & Physician & 15 years & Yes & Yes & $36 / 2500$ & $1 / 2000$ & $\begin{array}{l}0.04 \text { MN (scoping) } \\
0.008 \text { Dic (scoping) }\end{array}$ \\
\hline 4 & 36 & M & Physician & 10 years & Yes & Yes & $17 / 1000$ & $1 / 1000$ & $\begin{array}{l}0.04 \text { Gy MN (X-Ray+scoping) } \\
0.012 \text { GyDic (X-Ray+scoping) }\end{array}$ \\
\hline 5 & 37 & M & Physician & 10 years & No & Yes & $8 / 1000$ & $1 / 2000$ & $\begin{array}{l}\text { MN frequency is within natural limits } \\
0.005 \text { GyDic (3 PA graphy) }\end{array}$ \\
\hline 8 & 30 & M & Physician & 5 years & Yes & Yes & $14 / 1000$ & $0 / 500$ & 0.02 Gy MN (CT+PA X-Ray \\
\hline 9 & 31 & M & Physician & 4.5 years & Yes & Yes & $48 / 3000$ & $1 / 1500$ & $\begin{array}{l}0.04 \text { MN (scoping) } \\
0.005 \text { Dic (scoping) }\end{array}$ \\
\hline 10 & 35 & M & Physician & 4 years & Yes & Yes & $10 / 1000$ & $2 / 2500$ & $\begin{array}{l}\text { MN frequency is within natural limits } \\
0.01 \text { Gy (CT) }\end{array}$ \\
\hline
\end{tabular}

distances should be predetermined. Without compromising the diagnostic objective, the general rule should be to apply as little ionizing radiation as possible and to comply with all the requirements of ionizing radiation.

Ethics Committee Approval: Authors declared that the research was conducted according to the principles of the World Medical Association Declaration of Helsinki "Ethical Principles for Medical Research Involving Human Subjects", (amended in October 2013).

Informed Consent: Verbal informed consent was obtained from patients who participated in this study.

Peer-review: Externally peer-reviewed.

Author Contributions: Concept - B.Y., C.Ç., F.S.P.; Design - B.Y., C.Ç., F.S.P.; Supervision - B.Y., C.Ç., F.S.P.; Resources - B.Y., C.Ç., F.S.P., K.T., M.Ö., M.Ç.; Materials - B.Y., C.Ç., F.S.P., K.T., M.Ö., M.Ç.; Data Collection and/or Processing - B.Y., C.Ç., F.S.P., K.T., M.Ö., M.Ç.; Analysis and/or Interpretation - B.Y., F.S.P., K.T.; Literature Search - B.Y., K.T., F.S.P., C.Ç.; Writing Manuscript - B.Y., C.Ç., F.S.P., K.T.; Critical Review - B.Y., K.T., F.S.P., C.Ç., M.Ö., M.Ç.; Other - B.Y., K.T., F.S.P., C.Ç., M.Ö., M.Ç.

Conflict of Interest: No conflict of interest was declared by the authors.

Financial Disclosure: The authors declared that this study has received no financial support.

\section{REFERENCES}

1. Gönen E, Ergün E. Ameliyathanede radyasyondan korunma klavuzu. Türk Ortopedi ve Travmatoloji Birliği Derneği Yayınları 2015; 2-15.

2. Yücel D, Palacı H, Timlioğlu S, Şahan Ö, Okur H. Hasta ve çalışan güvenliği kapsamında radyasyon güvenliği hizmet içi eğitim programının etkinliğine ilişkin bir örnek olay çalışması. Uluslararası sağlıkta performans ve kalite kogresi; Bildiriler kitabı 2009; 2: 133-44.

3. Rahman N, Dhakam S, Shafqut A, Qadir S, Tipoo FA. Knowledge and practice of radiation safety among invasive cardiologists. J Pak Med Assoc 2008; 58: 119-22.

4. Johnson RH Jr. The role of the radiation safety specialist as witness: risk communication with attorneys, judges, and jurors. Health Phys 2001; 81: 661-9. [CrossRef]

5. Brenner DJ, Doll R, Goodhead DT, Hall EJ, Land CE, Little JB, et al. Cancer risks attributable to low doses of ionizing radiation: assessing what we really know. Proc Natl Acad Sci U S A. 2003; 100: 13761-6. [CrossRef]
6. Akbar-Khanzadeh F, Jahangir-Blourchian M. Ultraviolet radiation exposure from UVtransilluminators. J Occup Environ Hyg 2005; 2: 4936. [CrossRef]

7. Cebulska-Wasilewska A. Response to challenging dose of X-rays as a predictive assay for molecular epidemiology. Mutat Res 2003; 544: 289-97. [CrossRef]

8. Norppa H, Bonassi S, Hansteen IL, Hagmar L, Strömberg U, Rössner $P$, et al. Chromosomal aberrations and SCEs as biomarkers of cancer risk. Mutat Res 2006; 600: 37-45. [CrossRef]

9. Labay K, Ould-Elhkim M, Kles V, Guffroy M, Poul JM, Sanders P. Effects of griseofulvin in medium-term liver carcinogenesis assay and peripheral blood micronucleus test in rat. Teratog Carcinog Mutagen 2001; 21: 441-51. [CrossRef]

10. Majer BJ, Laky B, Knasmuller S, Kassie F. Use of the micronucleus assay with exfoliated epithelial cells as a biomarker for monitoring individuals at elevated risk of genetic damage and in chemoprevention trials. Mutat Res 2001; 489: 147-72. [CrossRef]

11. Pastor S, Gutierrez S, Creus A, Xamena N, Piperakis S,Marcos R. Cytogenetic analysis of Greek farmers using the micronucleus assay in peripheral lymphocytes and buccal cells. Mutagenesis 2001; 16: 539-45. [CrossRef]

12. Schweikl H, Schmalz G, Spruss T. The induction of micronuclei in vitro by unpolymerized resin monomers. J Dent Res 2001; 80: 1615-20. [CrossRef]

13. Hessel H, Radon K, Pethran A, Maisch B, Grobmair S, Sautter I, et al. The genotoxic risk of hospital, pharmacy and medical personnel occupationally exposed to cytostatic drugsevaluation by the micronucleus assay. Mutat Res 2001; 497: 101-9. [CrossRef]

14. Garewal HS, Ramsey L, Kaugars G, Boyle J. Clinical experience with the micronucleus assay. Cellular Biochem 1993; 17: 206-12. [CrossRef]

15. Maluf SW, Erdtmann B. Genomic instability in Down syndrome and Fanconi anemia assessed by micronucleus analysis and singlecell gel electrophoresis. Cancer Genet Cytogenet 2001; 124: 71-5. [CrossRef]

16. Schneider M, Diemer K, Engelhart K, Zankl H, Trommer WE, Biesalski HK. Protective effects of vitamins $C$ and $E$ on the number of micronuclei in lymphocytes in smokers and their role in ascorbate free radical formation in plasma. Free Radic Res 2001; 34: 209-19. [CrossRef]

17. Rozgaj R, Kasuba V. Chromosome aberrations and micronucleus frequency in anaesthesiology personnel. Arh Hig Rada Toksikol 2000; 51: 361-8. 
18. Naccarati A, Molinu S, Mancuso M, Siciliano G, Migliore L.Cytogenetic damage in peripheral lymphocytes of mitochondrial disease patients. Neurol Sci 2000; 21: 963-5. [CrossRef]

19. Cruz AD, McArthur AG, Silva CC, Curado MP, Glickman BW. Human micronucleus counts are correlated with age, smoking, and cesium-137 dose in the Goiania (Brazil) radiological accident. Mutat Res 1994; 313: 57-68. [CrossRef]
20. Grelat M, Greffier J, Sabatier P, Dauzac C, Lonjon G, Debono B, et al. Assessment of the Radiation Exposure of Surgeons and Patients During a Lumbar Microdiskectomy and a Cervical Microdiskectomy: A French Prospective Multicenter Study. World Neurosurg 2016; 89: 329-36. [CrossRef]

21. Attigah N, Oikonomou K, Hinz U, Knoch T, Demirel S, Verhoeven E, et al. Radiation exposure to eye lens and operator hands during endovascular procedures in hybrid operating rooms. J Vasc Surg 2016; 63: 198-203. [CrossRef] 